\title{
Menjadikan Manajemen sebagai Paradigma Pembangunan dalam Mewujudkan Good Governance
}

\section{Muqodim}

One of main causes for multicrisis in Indonesia are mismanagement and moral hazard problem in every sectors. Political situation and economy is a two sides which linked each other. So far, executives in government mostly see politics and economy as the effort to gain power for individuals or groups, fully ignoring the essential task for manager to maintain the country using good management principles which will enable to rise sustainable value of creation. The core conditions of the success of nation building is through well understanding toward the proposed goal, i.e. independency, developed, and welfare in national life. The only way to attain is to maintain this country by utilizing good management.

ewasa ini pembangunan lebih banyak dipahami sebagai sebuah momen politis dan historis daripada manajemen. Walaupun harus dipahami dari dua aspek, secara politik dan secara manajemen, nampaknya pembangunan lebih menarik jika dipahami sebagai sebuah praktik politik daripada praktik manajemen. Kenyataan inilah yang membuat pembangunan di negara-negara berkembang termasuk Indonesia sebagai development of the underdeveloped. Yang dibangun adalah keterbelakangannya padahal seharusnya yang dibangun adalah rakyat dan negara. Guru manajemen Peter F. Drucker setuju dengan pepatah yang populer di Amerika Latin "there is never underdeveloped country, there is always undermanaged country. Sebenarnya tidak ada negeri yang terbelakang, yang ada adalah negara yang tidak dimanajemeni dengan baik. Oleh karena itu tulisan ini mencoba mencari alternatif pendekatan pembangunan secara kom- prehensip dan berkelanjutan, sehingga hasilhasil pembangunan bisa dirasakan oleh rakyat sebagai pemegang kedaulatan.

\section{Persoalan Pembangunan Ekonomi}

Pembangunan di Indonesia sebenarnya sudah dimulai sejak kemerdekaan, yang dimulai dari pembangunan politik-sosial dengan memfokuskan pada bangunan politik sosial yang kuat guna menciptakan negara yang berdaulat untuk kemudian mampu meletakkan dasar pembangunan ekonomi. Pembangunan ekonomi sendiri baru memperoleh bentuknya sesudah tahun 1970, yaitu pada masa Orde Baru. Namun dalam perjalanannya pembangunan Indonesia membawa keberhasilan dan sekaligus kegagalan. Sampai awal tahun 1997 pertumbuhan ekonomi Indonesia masih optimis $8 \%$, dan menjadi contoh keberhasilan pembangunan. Namun krisis moneter mulai pertengahan tahun 1997 telah menciptakan suasana chaos yang 
melembaga yang masih terasa hingga hari ini.

Kekidakberhasilan pembangunan pra krisis, pada masa Orde Lama dan Orde Baru, maupun pasca krisis menyisakan paling tidak ada tiga persoalan besar, di bidang ekonomi, yang mesti dihadapi oleh pemerintahan hasil pemilu 2004, yakni jumlah pengangguran yang luar biasa besar, belum bergulirnya sektor riil dan beban utang negara yang besar sekali. Ketiga masalah tersebut melilit seperti lingkaran setan penyebab mandeknya kondisi ekonomi bangsa.

Data tahun 2003 (Kontan, No 31, 2004) menyebutkan jumlah penganggur sungguhan (orang usia kerja yang sungguhsunguh tak mempunyai pekerjaan) mencapai 10 juta orang. Ini berarti mencapai $10 \%$ dari total angkatan kerja, yang tahun 2004 ini diperkirakan mencapai 104 juta orang. Salah satu penyebab meningkatnya pengangguran adalah belum bergulirnya sektor riel. Lapangan kerja yang tercipta untuk menyerap pengangguran masih sangat terbatas. Padahal pertumbuhan angka pekerja setiap tahun mencapai 2 juta orang.

Pergerakan sektor riil yang lambat tersebut terkait dengan minimnya suntikan dana bagi pelaku usaha. Kalau diinginkan ada tingkat pertumbuhan ekonomi sekitar $5 \%$ pertahun, total kebutuhan investasi bagi Indonesia saat ini sekitar Rp 380 trilyun. Sementara jumlah investasi yang masuk masih berkisar Rp 110 trilyun. Padahal dua pasangan calon presiden mentargetkan pertumbuhan ekonomi rata-rata selama lima tahun lebih dari $6 \%$. Tentu saja jika diinginkan tingkat pertumbuhan lebih tinggi $5 \%$ kebutuhan dana lebih besar lagi.

Utang pemerintah saat ini merupakan warisan pemerintah masa yang lalu. Utang luar negeri kita kita sekarang ini mencapai US $\$ 75$ milyar lebih atau sekitar $40 \%$ dari total produk Domestik Bruto (PDB) Rp 1.800 trilyun. Sementara itu utang dalam negeri mencapai Rp 600 trilyun lebih. Maka tidak bisa dihindari bahwa sebagian besar alokasi anggaran pendapatan dan belanja negara terserap untuk membayar cicilan utang dan bunganya, bukan untuk menggerakkan sektor riil atau belanja pemerintah.

Uraian di atas menunjukkan bahwa sampai dalam usia ke 59 Republik Indonesia, negara belum dimanajemeni secara baik. Kita sering gagal dalam membangun atau gagal mempertahankan kesinambungan keberhasilan pembangunan. Oleh karena itu dekonstruksi ke depan setelah pemilu legislatif dan pemiilu presiden - wakil presiden adalah mewujudkan good governance untuk pencapaian visi yang telah ditetapkan. Untuk itu diperlukan adanya paradigma pembangunan yang dapat mengatasi kelemahan periode sebelumnya.

\section{Paradigma Politik dan Paradigma Manajemen}

Permasalahan yang rumit sebagaimana diuraikan diatas dapat disederhanakan dan kemudian dipecahkan dengan melihat pembangunan negara ke depan tidak semata-mata dari perspektif politik tapi harus dengan perspektif manajemen. Perbedaan pokok antara perspektif politik dan perspektif manajemen (Dwijowijoto, 2003) adalah terletak pada ruh dari masingmasing. Politik lebih berkenaan dengan kekuasaan dan kekuasaan selalu tunggal, serta diperebutkan di antara kelompokkelompok politik yang saling bersaing satu sama lain. Setelah krisis ekonomi tahun 1997 dan berlanjut dengan krisis multi dimensi yang melanda Indonesia pembangunan demokrasi di Indonesia berjalan 
cukup baik. Pemilihan umum sebagai cerminan demokrasi telah berjalan lebih demokratis, walaupun mungkin belum mendapatkan pemimpin yang mampu untuk memecahkan permasalahan bangsa. Terbukti sejak krisis telah tiga kali Indonesia mempunyai pemimpin baru dan sampai sekarang hasil-hasil konkret pemecahan masalah belum tampak. Hal ini akan terlihat jelas bila dibandingkan dengan negara Asia lain yang juga dilanda krisis seperti Thailand dan Korea Selatan. Kedua negara tersebut sudah beberapa tahun yang lalu dapat mengatasi masalah krisis yang dihadapinya.

Ketidakberhasilan pembangunan disebabkan karena pemahaman paradigma politik yang menganggap politik identik dengan kekuasaan. Kekuasaan dalam politik dianggap mempunyai ruh tunggal, dan di negara berkembang sering disebut "zero sum game". Kalau yang satu menang yang lain harus kalah. Kalau yang satu mau berhasil, yang lain perlu menghambat. Akibatnya pembangunan menjadi tidak berkesinambungan karena ganti penguasa ganti peraturan. Peraturan adalah bukti kekuasaan dan kekuasaan adalah inti dari politik, "power is the core of the politics"

Dalam manajemen, segala sesuatu dilihat sebagai sebuah upaya untuk mengoptimalkan asset yang ada, termasuk asset yang diberikan oleh manajemen sebelumnya. Ruh paradigma manajemen dalam pembangunan adalah kontinyuitas. Di Amerika Serikat, misalnya, apakah yang menang Partai Republik atau Partai Demokrat pembangunan yang dilakukan berlangsung dalam sebuah kontinum. Demikian juga di Australia apakah yang menang Partai Buruh atau Partai Liberal pembangunan tetap berkelanjutan. Hal ini terjadi karena pendekatan yang dilakukan adalah politik masuk dalam paradigma manajemen (Dwijowijoto, 2003). Sebaliknya di sebagian negara berkembang kegagalan dalam membangun bukan semata-mata karena gagal membangun itu sendiri, tetapi lebih karena kegagalan mempertahankan - kesinambungan keberhasilan pembangunan. Kegagalan itu dikarenakan oleh cara memahami pembangunan yang lebih dominan dari perspektif politik sebagai strugle of power. Sudut pandang seperti ini mengandung dua konsekuensi

1. Mereka yang sedang duduk di kekuasaan akan berusaha bertahan selama mungkin dalam rangka mempertahankan keberhasilan pembangunan.

2. Mereka yang menggantikan sebagai penguasa baru akan menumbangkan bangunan yang sudah diciptakan penguasa sebelumnya.

Menurut Dwijowiyoto (2003) seharusnya pembangunan dimunculkan sebagai isu manajemen bukan isu politik semata. Pembangunan yang dipahami dalam makna manajemen berarti bahwa terjadi proses value creation yang berkelanjutan. Pendekatan manajemen juga berarti mementingkan kerjasama tim, baik pada tingkat administrasi publik maupun tingkat kebangsaan. Kerja sama pada tingkat administrasi publik melibatkan eksekutif dan legislatif serta perangkat pendukung di daerah. Kerja sama tingkat kebangsaaan melibatkan negara (administrasi publik) dan masyarakat, baik lembaga bisnis maupun lembaga nirlaba, baik di tingkat nasional maupun lokal. Pemerintahan baru harus berusaha sekuat tenaga menuju "strong state and strong society", bukan "strong state and weak society". Hasil akhir dari proses kerja sama tim adalah kemanfaatannya bagi rakyat sebagai 'pemegang saham' atau pemegang kedaulatan. 
Pembangunan yang berkelanjutan berarti bahwa siapapun nanti yang menjadi penguasa baru setelah pemilihan presiden dan wakil presiden putaran kedua bulan September 2004, tugas pertama bukan asal "membongkar kembali" bangunan yang telah dibuat pendahulunya, melainkan melanjutkan pondasi yang sudah baik atau minimal mengkapitalisasi asset produktif yang ditinggalkan pendahulunya. Tentu saja pemerintahan baru juga harus menghilangkan sisi-sisi kelemahan pemerintahan sebelumnya..

Pembangunan harus dilakukan dengan manajemen yang baik, karena manajemen yang baik membuat organisasi berfungsi secara optimal. Dalam konsep besarnya manajemen merupakan urutan pekerjaan yang metodologis, sekuensial dan dapat dibenarkan secara keilmuan. Manajemen adalah sistem, yang mengarahkan kumpulan manusia menuju tujuan bersama yang baik bagi dirinya maupun orang lain. Manajemen adalah disiplin, untuk membangun tim. Tanpa adanya tim, individu-individu yang ada akan berusaha mencapai tujuan pribadi. Manajemen adalah pembelajaran. Tanpa pembelajaran dan sistem hanya bekerja untuk hari ini karena tidak ada kemampuan untuk menyesuaikan diri dengan perubahan yang terjadi di masa depan. Oleh karena itu manajemen adalah inovasi. Konsistensi penyelenggaraan pembangunan tidak berarti identik dengan kekakuan, tetapi justru menekankan disiplin. Salah satu disiplin yang diperlukan untuk mempertahankan momentum pembangunan adalah disiplin berinovasi. Salah satu kegagalan Orde Baru dalam mempertahankan kinerja pembangunannya adalah penggunaan paradigma pembangunan tahun 1970-1980 untuk mengelola pembangunan tahun 1990. Dalam manajemen Orde Baru tidak menggunakan pembelajaran dan inovasi sebagai sebuah kebudayaan organisasi.

Sebagaimana praktik manajemen strategis "dalam organisasi swasta, konsistensi penyelenggaraan pembangunan negara yang berkelanjutan hendaknya selalu dimulai dari visi dan misi, dilanjutkan dengan strategi, kemudian diteruskan implementasi dan pada setiap tahapan selalu dilakukan pengendalian, dan ujungnya diakhiri dengan pengawasan. Untuk kemudian masuk ke proses perencanaan kembali membentuk daur yang berkesinambungan.

\section{Visi, Misi dan Strategi Pembangunan menuju Good Governance}

Satu hal yang menjadi prasyarat keberhasilan pembangunan adalah adanya kejelasan Visi dan Misi. Setiap negara harus mempunyai visi karena akan memberikan kejelasan bagi manajemen pengelola negara mengenai apa yang ingin dituju dan kondisi apa yang ingin dicapai. Ketidakjelasan visi menyebabkan arah pembangunan selalu berubah-ubah dan tidak berkesinambungan. Di samping itu, setiap negara juga memerlukan kejelasan misi sebagai alasan mengapa keberadaan organisasi negara tersebut.

Visi Indonesia masa depan terletak pada kesepakatan kehidupan berbangsa dan bernegara. Visi dari pembangunan adalah terwujudnya masyarakat yang maju, mandiri, sejahtera, adil dan setia kepada Pancasila dan UUD 1945. Dalam konteks kekinian, agar Visi tersebut sesuai dengan paradigma dan pendekatan pembangunan maka Visi tersebut perlu dirumuskan dan dijadikan dasar kebijakan dan strategi jaringan pembangunan dan pertumbuhan kawasan. Dengan dasar tersebut rumusan visi yang ditawarkan di bidang pembangunan 
ekonomi adalah terwujudnya pertumbuhan dan pemerataan pembangunan yang didukung oleh kekuatan perekonomian kawasan, kehandalan jaringan kawasankawasan pembangunan dan pertumbuhan serta kemampuan manajerial yang berdaya saing.

Visi mempunyai jangka wàktu yang boleh dikatakan tak terbatas, karena sifat dari kemajuan, kemakmuran, kemandirian, kesejahteraan dan keadilan bersifat relatif, tergantung pada waktu. Oleh karena itu perlu disusun pula visi selama satu periode kepemimpinan nasional, yang disesuaikan dengan tantangan dan kebutuhan yang harus dijangkau dalam lima tahun ke depan.

Misi setiap negara adalah menciptakan kesejahteraan bagi rakyatnya. Untuk Indonesia hal itu tertuang dalam Pembukaan UUD 1945, yaitu melindungi segenap bangsa Indonesia dan seluruh tumpah darah Indonesia dan untuk memajukan kesejahteraan umum, mencerdaskan kehidupan bangsa dan ikut melaksanakan ketertiban dunia yang berdasarkan atas kemerdekaan, perdamaian abadi dan keadilan sosial. Dalam konteks kekinian, maka misi pembangunan disempurnakan lagi dengan mencermati kondisi obyektif dalam masyarakat, yaitu adanya kesenjangan sebagai tantangan pembangunan. Oleh karena itu secara lebih fokus, misi pembangunan Indonesia adalah menanggulangi kesenjangan, memper-siapkan kompetensi global dan menjaga kesinambungan hidup bangsa dengan pembangunan untuk rakyat, dilaksanakan oleh rakyat sesuai aspirasi yang tumbuh dari rakyat.

Dari sisi manajemen, dalam pelaksanaan misi negara perlu dilakukan pemilihan strategi yang tepat. Strategi yang dipilih hendaknya berlandaskan pada kesinambungan dari sukses pembangunan yang telah diraih. Pertama, strategi pembangunan ekonomi harus diselenggarakan atas asas kesamaan hak dari seluruh warga negara untuk melakukan akses terhadap sumber daya ekonomi. Sehingga kekuatan ekonomi tidak hanya berada pada sejumlah kecil kelompok ekonomi raksasa. Kedua, strategi pembangunan ekonomi hendaknya mempertautkan antara sektor yang ditopang oleh sumber dava alam seperti: pertanian, kehutanan, perkebunan, kelautan, peternakan dan pertambangan dengan sumber daya yang ditopang oleh kemodernan.atau sektor industri baik manufaktur maupun jasa. Berarti pembangunan sektor industri modern harus berjalan seiring dengan pembangunan sektor pertanian, kehutanan, perkebunan dan lainlain., Hal ini berarti bahwa pembangunan ekonomi tetap harus menekankan kepada keseimbangan antara pertumbuhan dan pemerataan.

Kemudian apabila strategi yang telah dipilih, langkah berikutnya strategi tersebut diimplementasikan dalam rangka mencapai visi yang telah ditetapkan secara efektif dan efisien. Efektivitas dan efisiensi tersebut bisa dicapai apabila negara dikelola dengan mendasarkan pada prinsip-prinsip good governance. Karena dengan dasar prinsipprinsip good governance itu pihak-pihak yang berkepentingan akan selalu mempertanyakan secara kritis pelaksanaan pembangunan. Misalnya: apakah organisasi telah disusun sesuai dengan misi yang diembannya dan sesuai dengan visi yang telah dirumuskan? Dalam hal ini, tidak seenaknya presiden terpilih membentuk depatemen baru atau menghapus departemen lama. Kemudian, pertanyaan lainnya, apakah penyelenggaraan negara dapat dipertanggungjawabkan secara sosial, politik, ekonomi maupun moral?. Dengan pertanyaan-pertanyaan seperti itu maka setiap pejabat negara merasa selalu 
dikontrol dan diawasi oleh berbagai pihak dalam melaksanakan pembangunan. Mereka tidak hanya bertanggung jawab secara politik dan formal konstitusional, tetapi juga bertanggung jawab secara sosial dan moral. Rambu-rambu semacam itu akan menghasilkan daya preventif terhadap penyimpangan yang diakibatkan kelemahan perangkat peraturan.

Soedjais (2002) mengatakan bahwa good government berkenaan dengan masalah bagaimana suatu organisasi (negara) ditata dan bagaimana tatanan tersebut berproses. Dengan demikian negara sebagai sebuah organisasi harus mempunyai ukuran-ukuran proses, yang paling tidak menyangkut empat hal berikut: 1). Transparency, 2). Fairness; 3). Accountability; dan 4). Responsibility.

1. Transparency dibangun atas dasar kebebasan arus informasi. Prosesproses, lembaga-lembaga dan informasi secara langsung dapat diterima oleh mereka yang membutuhkan. Informasi harus dapat dipahami dan dimonitor. Tranparansi menunjukkan perbaikan terhadap keterbukaan informasi.

2. Fairness ditujukan kepada pihak-pihak minoritas sehingga mendapat perlindungan dari tindakan-tindakan yang merugikan mereka.

3. Accountability merupakan tanggung jawab manajemen melalui pengawasan yang efektif berdasarkan keseimbangan wewenang antara eksekutif, legislatif, dan yudikatif.

4. Responsibility berarti lembaga lembaga publik harus taat kepada hukum yang berlaku dan bertindak sesuai dengan kebutuhan masyarakat. Lembaga -lembaga dan proses harus mencoba untuk melayani setiap stakeholders.
Empat prinsip tersebut di atas harus menjadi acuan bagi pemerintah dan rakyatnya agar pembangunan bermanfaat sepenuhnya untuk menyejahterakan rakyat. Ke empat ukuran tersebut juga relevan diterapkan pada sektor swasta baik yang berorientasi laba maupun nirlaba dengan istilah good corporate governance. Seperti hainya dalam good corporate governance, maka good governance juga harus mengimplementasikan fungsi-fungsi manajemen seperti: planning, organizing, leading (termasuk implementing) dan controlling. Dalam pelaksanaan good governance, controlling atau pengendalian tidak boleh diabaikan. Pengendalian dalam hal ini adalah memastikan sejauh mana implementasi good governance dapat dijalankan. Penerapan good governance kepada pemerintah adalah ibarat masyarakat memastikan bahwa mandat, wewenang, hak dan kewajibannya telah dipenuhi dengan sebaik-baiknya. Jadi arah ke depan dari good governance adalah membangun pemerintahan yang profesional, yaitu pemerintahan yang dikelola oleh mereka yang mempunyai ilmu, pengetahuan dan pangalaman, yang mampu mentransfer ilmu, pengetahuan dan pengalaman menjadi skill, dan dalam melaksanakannya berlandaskan etika dan moralitas yang tinggi.

Untuk menuju ke pemerintahan seperti itu bukanlah paradigma politik sebagai paradigma yang melandasi pembangunan tetapi seharusnya paradigma manajemen, yang digunakan sebagai landasan pembangunan.

Penggunaan paradigma manajemen sebagai paradigma pembangunan tersebut sudah disinyalkan oleh Peter F. Druker pada tahun 1999 sebagai berikut "the center of a modern society, economy and community is not technology. It is not information. It is 
not productivity. It is the managed institution as the organ of society to produce result". Di masa mendatang hanya negara bangsa yang memiliki organisasi dan manajemen yang efektiflah yang akan dapat memenangkan persaingan, karena hanya dengan manajemen (dimulai dari pemerintah) yang efektif yang mampu menghasilkan kebijakan publik yang efektif dalam membangun iklim the efektif culture bagi organisasi publik itu sendiri, maupun organisasi bisnis dan nir laba.

\section{Kesimpulan}

Agar pelaksanaan pembangunan berdampak pada peningkatan kesejahteraan rakyat maka pemerintahan baru harus bisa menerapkan good governance secara baik. Untuk itu diperlukan perubahan paradigma pembangunan dari pendekatan perspektif politik semata menjadi pendekatan dari perspektif manajemen. Dalam hal ini manajemen tidak dipahami sebagai sesuatu yang teknis, tetapi sebagai paradigma manajemen merupakan sesuatu yang filosofis. Paradigma manajemen akan lebih menjamin adanya keberlanjutan pembangunan yang berorientasi ke kesejahteraan rakyat. Ke empat prisip good governance: transparansi, fairness, akuntabilitas dan resposibilitas harus terus menerus ditingkatkan.

Pelaksanaan good governance dalam pemerintahan yang baru, hasil pemilu 2004, dimulai dari perlunya secara sungguhsungguh mengatur pemisahan antara jabatan politik (di partai politik) dengan jabatan kenegaraan (pejabat negara), diteruskan berkomitmen terhadap visi dan misi, penentuan skala prioritas dan pemilihan strategi yang tepat, dan menjalankan fungsi-fungsi manajemen.
Dalam menjalankan fungsi-fungsi manajemen pemerintahan baru perlu membudayakan mànajemen dalam pengelolaan negara maupun organisasi lainnya.

\section{Daftar Pustaka}

Drucker, Peter, F., 1993, The Effetive Executive, New York: Harper Business.

Drucker, Peter, F., 1999, Management Challenges for the 21th Century, Oxford: Butterworth and Heinemman.

Dwidjowijoto, Riant Nugroho, 2003, Reinventeing Pembangunan, Menata Ulang Paradigma Pembangunan untuk Membangun Indonesia Baru dengan Keunggulan Global, Jakarta:Elex Media Komputindo.

Kontan, No 31, Tahun VIII, 10 Mei 2004.

Kotler, Philip dan Hermawan Kertajaya, 2000, Repositioning Asia, From Buble tó Sustainable Economy. Jakarta: Salemba Empat.

Kwik Kian Gie, 1998, Gonjang Ganjing Ekonomi Indonesia, Badai Belum Akan Berlalu, Jakarta: Gramedia Pustaka Utama

Rainey, Hal G., 1997, Understanding and Managing Public Organizations, San Francisco: Jossey-Bass.

Soedjais, Zainal, 2002, Good Governance, Daya Saing, dan Investasi Global,. Dipresentasikan pada Șeminar "Good Governance dan Kebijakan Baru di Bidang Investasi", Batam $10 \mathrm{Mei}$ 2002. 